\title{
Correlation between learning and alcoholization in rats
}

\section{Olga Kovalenko*,}

\section{Oleksandr Bondarenko,}

Irina Tubaltseva,

\section{Mukola Makarchuk}

Educational and Scientific Centre

"Institute of Biology and Medicine",

Taras Shevchenko

National University of Kyiv,

2 Academician Glushkov Avenue,

Kyiv 03022, Ukraine

\begin{abstract}
The aim of this work was to investigate the relationship between the processes of learning and innate behaviour and alcohol abuse in young male rats. Rats differed in the degree of alcohol motivation and had different combinations of training in maze with alcoholization. In general it was found that compared to nondependent animals, alcohol-dependent rats were characterized by much higer emotionality, anxiety, lower locomotor activity, and research activity. The most negative influence of alcohol abuse on the behaviour was shown in animals with low innate activity (locomotor, emotional, and exploratory activity), which were poorly trained in the maze. It was shown that training rats in the maze before alcohol abuse had a positive effect on the behaviour (slightly reduced the amount of alcohol-preferring animals). Alcoholization before training increased the level of anxiety and neurotic reactions in animals, especially in rats, which had poorly trained in maze before alcoholization. Alcoholization of animals before the start of training increased the level of anxiety and neurotic reactions in alcoholized rats, especially in those that were poorly trained in the maze before alcoholization.
\end{abstract}

Keywords: training, learning, innate behaviour, alcoholic motivation

\section{INTRODUCTION}

There is a series of experimental studies and clinical observations that show the dependence of alcoholic motivation and behavioural activity on individual and typological properties, such as the strength of the nervous system (Shabanov et al., 1999; David et al., 1999; Vengeliene et al., 2008; Risher et al., 2013), the initial activation level (Alexandrov et al., 1997; Batuev et al., 1999; Lopez et al., 2016), emotional labil-

\footnotetext{
*Corresponding author. Email: kl.olya@gmail.com
}

ity, and anxiety (Spanagel et al., 2014; Lopez et al., 2016; Vengeliene et al., 2008; Pfaff et al., 2007; Richard et al., 2006; Shabanov et al., 1999; Spanagel et al., 2014).

In particular, clinical studies have shown that chronic alcohol abuse in humans often precedes anxiety disorders, and not vice versa (Becker et al., 2011; Shabanov et al., 1999; Vengeliene et al., 2008; Romeo et al., 2006). In studies on the models of formation of alcohol dependence in animal, it was shown that anxiety level in Wistar rats in the elevated plus maze (EPM) positively correlates with alcohol consumption (Spanagel et al., 
2014). A study (Lopez et al., 2016) that shows that bilateral removal of the central nucleus of the amygdala, reduces the level of experimental anxiety, and leads to a decrease in the level of voluntary consumption of ethanol can be an indirect proof of this. In addition, assessing the behaviour of rats genetically selected for high levels of ethanol consumption (Risher et al., 2013) showed that rats were genetically predisposed to alcohol and had a higher congenital degree of anxiety than nondependent animals.

Also, a study on the effect of ethanol consumption on learning processes (Alexandrov et al., 2002; Batuev et al., 1999) has shown that the use of alcohol solution affects behavioural characteristics that show the expression of spatial-motor asymmetry in low-active rats. Since the fairness of various conceptions of the development and formation of alcoholism is still the subject of discussion, it is rather difficult to give them an exact assessment. Therefore, a complex analysis of the relationship between the level of alcoholic motivation and various aspects of inherent and acquired behaviour in animal models is needed in order to understand the pathogenetic mechanisms of this disease.

The purpose of this study was to identify the differences in general levels of locomotor and exploration activity, the anxiety-like behaviour in rats with different degrees of alcohol dependence at different combinations of alcoholism, and the processes of learning.

\section{MATERIALS AND METHODS}

Subjects. In the investigation, 254 white male rats (weight: 180-220 $\mathrm{g}$ at the beginning of the experiment) were tested. All manipulations were carried out according to bioethics rules.

Alcoholization. The chronic alcoholic intoxication was made in two steps: at stage I, the predisposition of rats to ethanol was determined by the "two bottles" method. The animals that had not had a previous contact with ethanol were placed into individual cages with two drinkers, one with water and the other with $15 \%$ solution of ethanol. At this stage, for the duration of 14 days, the animals had free choice between ethanol solution and water. The value of individual volume of consumed alcohol per unit time $(\mathrm{g} / \mathrm{kg} /$ day) and the percentage ratio of consumed alcohol and the volume of whole fluid were calculated once a day. It was described (Kovalenko et al., 2010) that the innate tendency to consume alcohol was linked to the level of behavioural responses, that was why this step allowed balancing rats in groups IV, V, and VI based on behavioural characteristics and also by the level of spontaneous alcohol consumption before the beginning of the 30day forced alcoholization. At stage II, forced alcoholization was performed by introducing ethanol as the sole source of fluid for 30 days. After that, to assess the individual level of alcohol consumption during four days, cages were equipped with two drinkers again (one with water, the other one with $15 \%$ solution of ethanol) (Parkhomenko et al., 2007).

Behavioural studies and separation into groups. At the beginning of the experiment, the behaviour of rats was evaluated using the open-field tests (Belzung and Griebel, 2001; Bogdanov et al., 2013). After testing, the rats were divided into two balanced groups:

Group A - conditioned reflex in the radial maze was produced in rats before chronic alcoholization;

Group B - conditioned reflex in the radial maze was produced in rats after chronic alcohol abuse.

The ability to learn in the radial maze was evaluated by the method of Yan Buresh before or after alcoholization for 14 days.

The radial maze (RM) consisted of a Plexiglas wall and a ceiling unit that was hinged to the wall. The maze had a transparent top and consisted of six numbered sleeves. The arms (25 cm long, $6 \mathrm{~cm}$ high, $6 \mathrm{~cm}$ wide) were closed and made of transparent Plexiglas (for testing spatial aspects of learning). At the end of each arm was a piece of cheese in the size of $4 \mathrm{~mm}$, blinded by a plastic shutter. Before training, the animals were food deprived and a habituation to the maze of one unreinforced trials of 
15 min with unlimited access to all arms was given. During the next 14 days, access to food remained free in three arms (Nos. 2, 3, and 5), and was limited in the other three (Nos. 1, 4, and 6). The test was started with the placement of a rat in the centre of the labyrinth and was ended with the taking of the last reinforcement, but not longer than for ten minutes. The rats could carry out one training per day. The following indicators were considered: latent period (LP, s) taking food reinforcements in open arms (the speed at which the task was performed); the number of errors (entry of an arm without the bait and entry of an arm where the bait had been previously consumed) (Buresh et al., 1991; Levin 2015). After completing training in RM and alcoholization, groups $\mathrm{A}$ and B were divided into six subgroups:

Subgroup I - "control WT" - intact animals, well trained in the labyrinth;

Subgroup II - "control PT" - intact animals, poorly trained in the labyrinth;

Subgroup III - "alcohol-preferring WT" - animals that preferred ethanol during alcoholization and well trained in the labyrinth;

Subgroup IV - "alcohol-preferring PT" - animals that preferred ethanol during chronic alcoholization and poorly trained in the labyrinth;

Subgroup V - "alcohol-non-preferring WT" - animals that preferred water during chronic alcoholization and well trained in the labyrinth;

Subgroup VI - "alcohol-non-preferring PT" - animals that preferred water during chronic alcoholization and poorly trained in the labyrinth.

Individual reactivity and the anxiety level of the rats were determined using the "open field" and "elevated plus maze" tests (Bogdanov et al., 2013; Buresh et al., 1991).

Elevated plus maze test (EPM). In the current study, the elevated plus maze was the main method for the evaluation of anxiety level in the rats from different groups. In this setup the following measures were recorded in the course of five minutes: time spent in closed and open arms, time spent in the centre, spend- ing time in the center, the number of entries made into either the open or the closed arms, the number of crossings of the central platform, the number of looks down, the number of looks from the centre, the quantity and duration of grooming (Bondarenko Oleksandr et al., 2014).

Open field test (OF). The experimental apparatus consisted of a $100 \times 100 \mathrm{~cm}$ arena and $40 \mathrm{~cm}$ high walls divided into 25 equal squares (16 peripheral and nine internal). An animal was placed in the centre of the arena and behavioural parameters were monitored for $5 \mathrm{~min}$, after which the animal was returned to its cage. Odour labels on the floor were avoided by wiping it with a damp cloth, after which testing of the next animal was started. Experiments were performed in a separate room with good sound insulation and a constant level of illumination (Volchegorskii et al., 2000). The various possible stressful influences from the environment were eliminated by placing the animals for a short period in a quiet, calm place shortly (about $24 \mathrm{~h}$ ) before testing, after which the test procedure was started (Gould, 2009). In this setup, the following measures were recorded in the course of five minutes: locomotor, emotional, and exploratory activity (the number of crossed central and peripheral squares - locomotor or exploratory activity; getting up on the hind legs - exploratory activity, grooming and defecation - emotional activity). Testing in the OF and EPM was carried out in the morning, one day before alcoholization and training in the RM, on the second and third day after the end of testing in the labyrinth (group B), and one day after the completion of alcoholization (group A).

The experiment was recorded with a video camera; all required parameters were measured during record examination. All behaviour was observed and analyzed with programmable Real Timer.

Data analysis. The data were analyzed with Statistica for Windows 7.0 (StatSoft). Since the distributions of most of the parameters obtained in these studies were different from normal (Shapiro-Wilk test), non-parametrical Mann-Whitney U-test was used for comparing 
independent groups. Differences were considered significant at $p \leq 0.05$. Median and interquartile range was used to describe the sampling distribution (Me [25\%, 75\%]).

\section{RESULTS}

Analysis of testing in RM (after training in $\mathrm{RM}$ and alcoholization) showed that in both experimental groups (group A and group B), alcoholization worsened the result of learning in RM and had a general negative effect on behaviour.

The number of errors and latency of taking the first and the last food reinforcement (LP1 and LP3) in alcoholic rats were generally higher than in control rats, especially in alcohol-nonpreferring subgroups. In group $A$ : $V(A)$ entry of an arm without the bait ( $p \leq 0.0003)$; IV(A) entry of an arm where the bait had been previously consumed ( $p \leq 0.03$ ). In group B: III (B) entry of an arm without the bait $(p \leq 0.03)$; $V(B)$ entry of an arm where the bait had been previously consumed ( $p \leq 0.0002)$; IV (B) entry of an arm without the bait $(p \leq 0.01)$ and entry of an arm where the bait had been previously consumed ( $p \leq 0.003$ ) (Fig. 1). The latent period taking the first and the last food reinforcements (LP1 and LP3): in group A (those that were well trained in the RM: in III (A) LP3 ( $p \leq 0.004)$, and V(A) LP3 $(p \leq 0.005)$ and those that were poorly trained in the RM: group VI (A) LP1 $(p \leq 0.03)$ ); and in group $\mathrm{B}$ (those that were well trained in the RM: III(B) LP3 ( $p \leq 0.01)$ and those that were poorly trained in the RM: IV (B) LP1 $(p \leq 0.07)$ (Fig. 2).

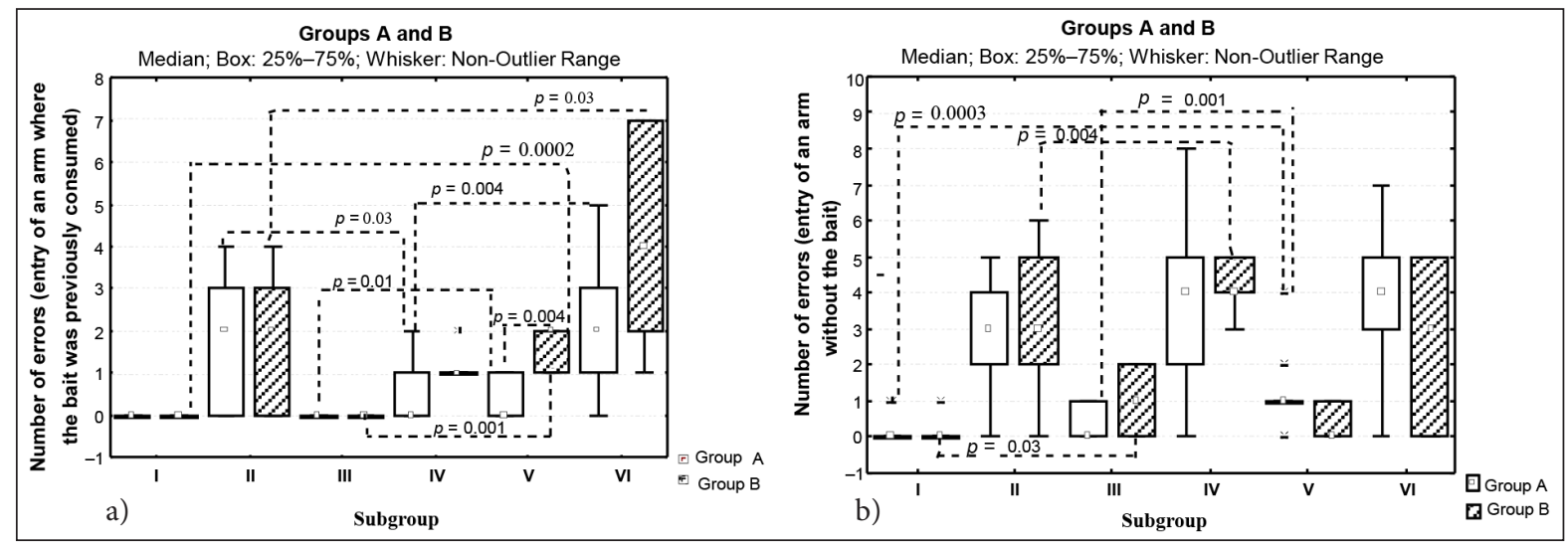

Fig. 1. Number of errors: entry of an arm without the bait (a) and entry of an arm where the bait had been previously consumed (b) in the radial maze in rats from group A and B subgroups I-VI
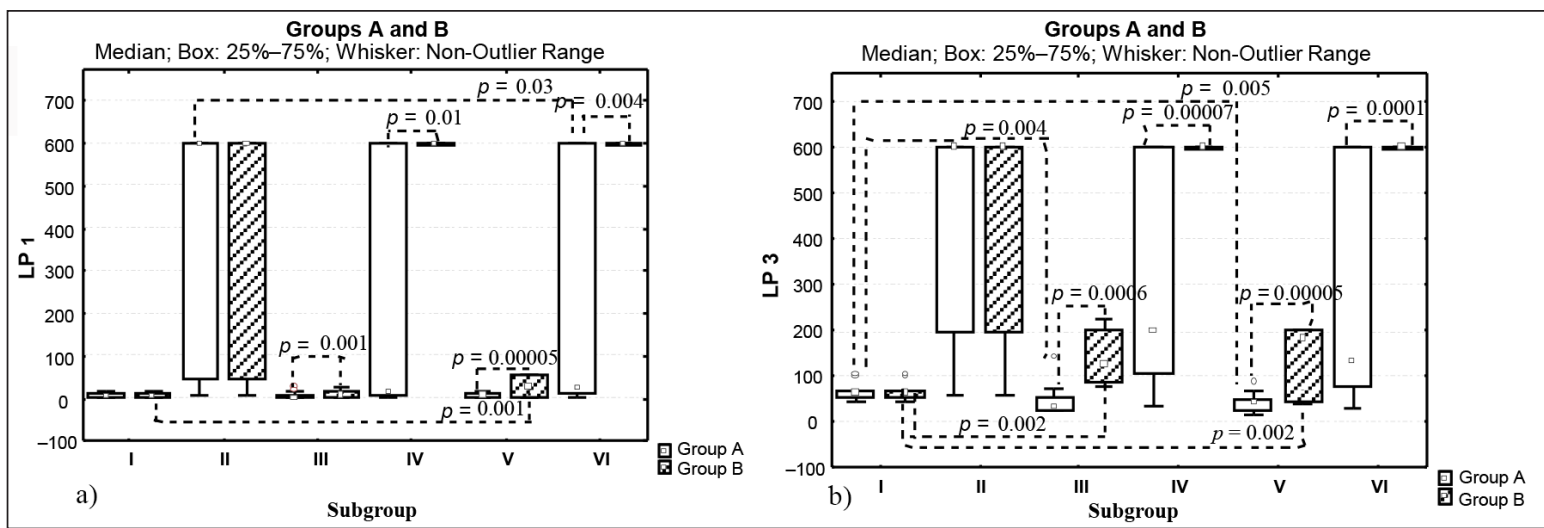

Fig. 2. Latent period taking the first (LP1) (a) and the last (LP3) (b) food reinforcements in the radial maze in rats from group $\mathrm{A}$ and $\mathrm{B}$ subgroups I-VI 
The difference in the ratios between alcohol-preferring and non-preferring rats was revealed, depending on the scheme of combining alcoholism and training in the RM. Namely: in group $\mathrm{A}$, the number of alcohol-dependent animals after alcoholization was higher by $53 \%$ than the number of alcohol-nondependent rats ( $p \leq 0.04$ ) (ratio 40/61). In group B animals, the ratio was $56 / 55$.

Differences in the success of training between groups $A$ and $B$ were also shown. The number of errors was significantly lower in rats that did not prefer ethanol from group A than in group $B$, and animals that consumed alcohol coped with the task of finding food in group A rather than in group B. This means that the rate of taking the first and the third food reinforcements (LP1 and LP3) was significantly higher in alcoholized animals of group A compared to group $B$, especially in the rats well trained in $R M$ (subgroups III and V). Subgroup III(A): LP1 $(p \leq 0.0008)$, LP3 ( $p \leq 0.0006)$; subgroup IV(A): LP1 $(p \leq 0.008)$, LP3 ( $p \leq 0.00004)$; subgroup $\mathrm{V}(\mathrm{A})$ : LP1 $(p \leq 0.00005)$, LP3 $(p \leq 0.00003)$, and subgroup VI(A): LP1 $(p \leq 0.004)$, LP3 $(p \leq 0.0001)$ (Fig. 2).

The number of errors in group A compared to group B: in subgroup $\mathrm{V}(\mathrm{A})$ (entry of an arm without the bait $(p \leq 0.007)$, entry of an arm where the bait had been previously consumed ( $p \leq 0.00008)$ ); subgroup VI(A) (entry of an arm where the bait had been previously consumed ( $p \leq 0.02$ ) (Fig. 1). In addition, in the rats of group $B$, there was an increase in the number of failures in the task of searching for food. Also, in well-trained rats from groups $A$ and $B$, those rats that preferred alcohol had significantly higher training parameters than the rats who did not prefer alcohol: in subgroup III (A) compared to the subgroup V (A), entry of an arm without the bait $(p \leq 0.001)$ and entry of an arm where the bait had been previously consumed ( $p \leq 0.01)$; in III (B) in comparison with the subgroup $\mathrm{V}(\mathrm{B})$, entry of an arm where the bait had been previously consumed ( $p \leq 0.001$ ) (Fig. 1).

Moreover, in alcoholized rats the differences between those that were well trained in the RM and those that were poorly trained in the RM were larger in group $B$ than in group A, namely: the number of errors in subgroup III(B) was less than in subgroup IV(B) (entry of an arm without the bait ( $p \leq 0.003$ ), in subgroup $\mathrm{V}(\mathrm{B})$ was less than in subgroup VI(B) entry of an arm without the bait $(p \leq 0.02)$, entry of an arm where the bait had been previously consumed $(p \leq 0.02))$, (Fig. 1). There was a higher rate of taking food reinforcement LP1 $(p \leq 0.0004)$, LP3 ( $p \leq 0.0008$ ) (Fig. 2).

Thus, in groups A and B, alcoholization reduced the learning outcomes in the labyrinth. But, despite the general negative impact of alcohol on animal behaviour, training before alcoholization (in group A) reduced the negative effects of ethanol on memory and learning functions.

Testing in the EPM showed a relationship between the baseline level of anxiety in animals and the ability to learn in the RM. So, in control subgroups of animals, the level of anxiety of rats of subgroup II was higher than in subgroup I, before and after training (before training: open arm time ( $p \leq 0.004)$, the number of crossings of the central platform $(p \leq 0.003))$. After training in the RM, the level of anxiety in rats of subgroup I remained lower than in rats of subgroup II (open arm time ( $p \leq 0.04$ ), the number of crossings of the central platform $(p \leq 0.03))$ (Fig. 3, 4).

The level of anxiety in alcohol-preferring animals that were well trained in the labyrinth was lower than in those rats that had been poorly trained before and after alcoholization. Thus, in subgroup IV (A), the number of closed arm entries was higher than in subgroup III (A) $(p \leq 0.03)$, while the number of open arm entries was lower $(p \leq 0.03)$; in addition, after alcoholization the differences between subgroups III (A) and IV (A) decreased. In subgroup IV (A), the number of closed arm entries was higher than in subgroup III (A) $(p \leq 0.03)$, and the number of open arm entries was lower $(p \leq 0.03))$. Alcoholization decreased the differences between subgroups III (A) and IV (A) (Fig. 3a).

After alcoholization, the overall anxiety level in subgroups III (A) and IV (A) became lower 
than in other subgroups: in subgroup III (A) increased number of head dips $(p \leq 0.04)$ and crossings of the central platform $(p \leq 0.04)$, and in the subgroup IV (A), number of open arm entries increased ( $p \leq 0.002)$, and number of head dips and crossings of the central platform decreased $(p \leq 0.04)(p \leq 0.04)$ (Fig. 3b). In group B as well as in group A, both before and after alcohol and training, the level of anxiety in the rats of subgroup III (B) was lower than in subgroup IV (B): before alcoholization in subgroup IV (B), the number of closed arm entries was higher compared with animals from subgroup III (B) $(p \leq 0.001)$, and the number of open arm entries and number of crossings of the central platform was lower $(p \leq 0.04))$ (Fig. 4a). After alcoholization and training in subgroup III (B), the number of open arm entries $(p \leq 0.03)$ increased and in comparison with subgroup IV (B) $(p \leq 0.04)$, the number of crossings of the central platform increased $(p \leq 0.03)$ in comparison with the sub- group IV (B) $(p \leq 0.04))$. In subgroup IV (B), the number of crossings of the central platform decreased $(p \leq 0.04)$ and the number of defecations increased $(p \leq 0.009)$ ) (Fig. 4b).

Thus, differences in the level of anxiety in rats were revealed, with varying degrees of alcoholic motivation and ability to learn in RM.

According to the results of testing in the OF, it can be said that ethanol increased the motor and exploratory activity of the animals (especially in rats that preferred ethanol) and reduced the level of emotional activity. Alcoholization of animals before the start of training (group B) reduced the level of individual reactivity. The most negative effect of alcoholization was observed in animals poorly trained in the RM. Thus, testing of the animals from group $\mathrm{A}$ in the OF before alcoholization and training showed that the animals not well trained in the RM had a low level of individual reactivity and a high level of emotionality, especially the animals from alcohol-
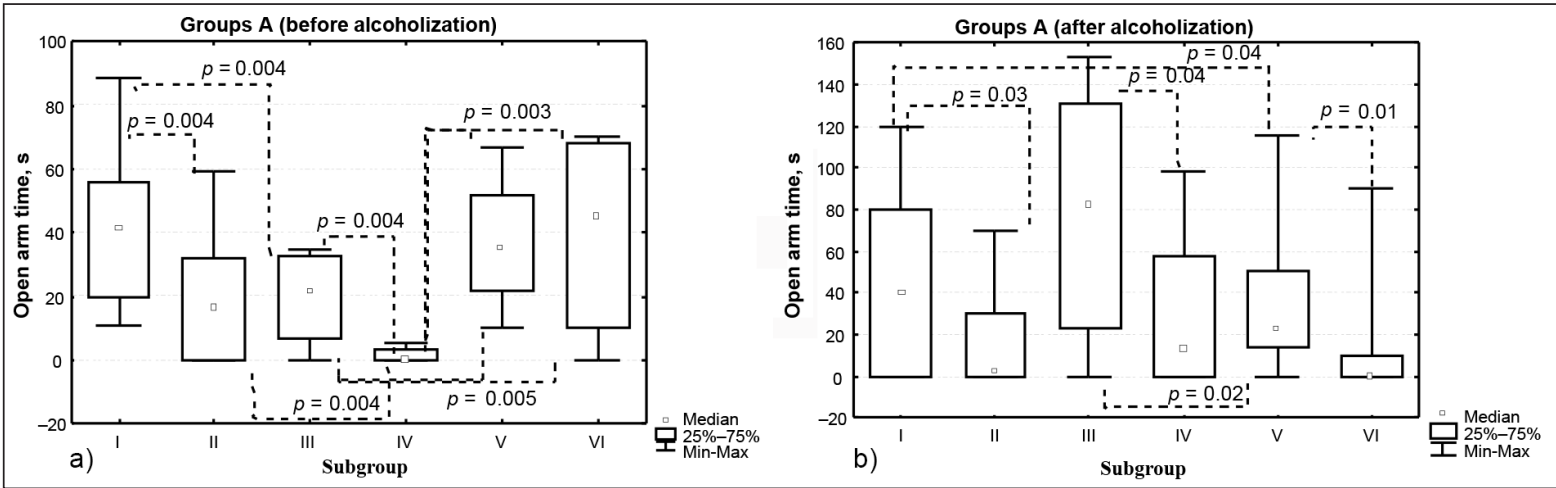

Fig. 3. Open arm time before (a) and after (b) alcoholization in the EPM in rats from group A, subgroups I-VI
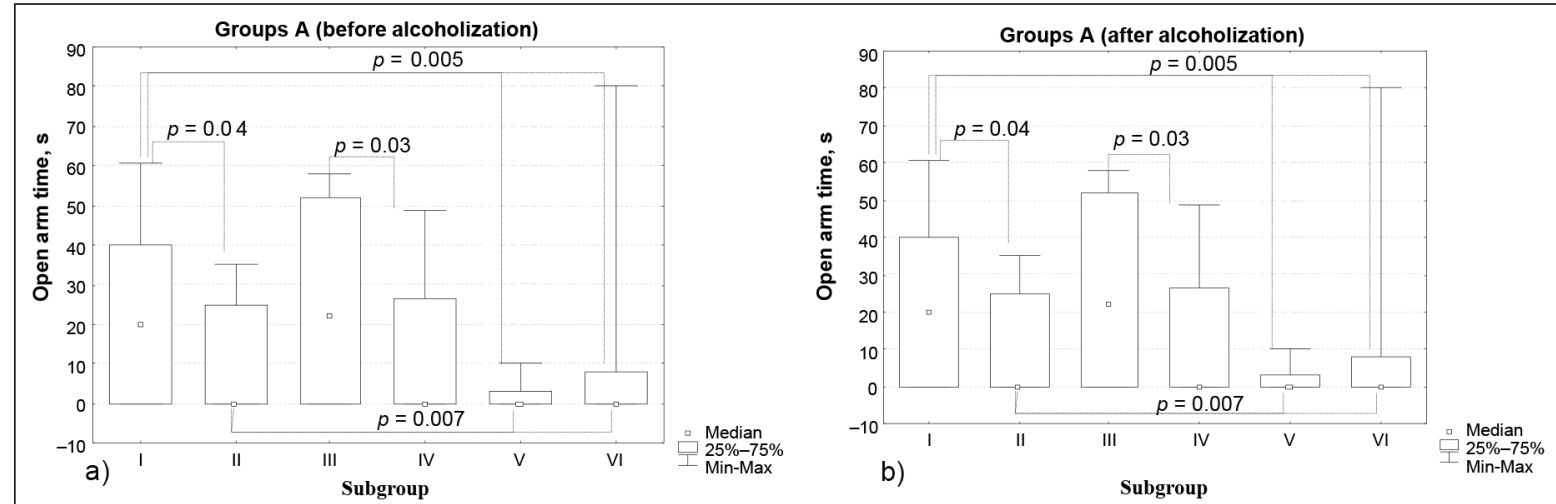

Fig. 4. Open arm time before (a) and after (b) alcoholization in the EPM in rats from group A, subgroups I-VI 
dependent subgroups: rats from subgroup III $(A)$ had a higher number of centre square entries $(p \leq 0.004)$ and the number of rears $(p \leq 0.03)$ compared with the rats from subgroup IV (A) (Fig. 5a, 7a). Among the alcohol-non-preferring subgroups: the rats from subgroup $\mathrm{V}$ (A) had

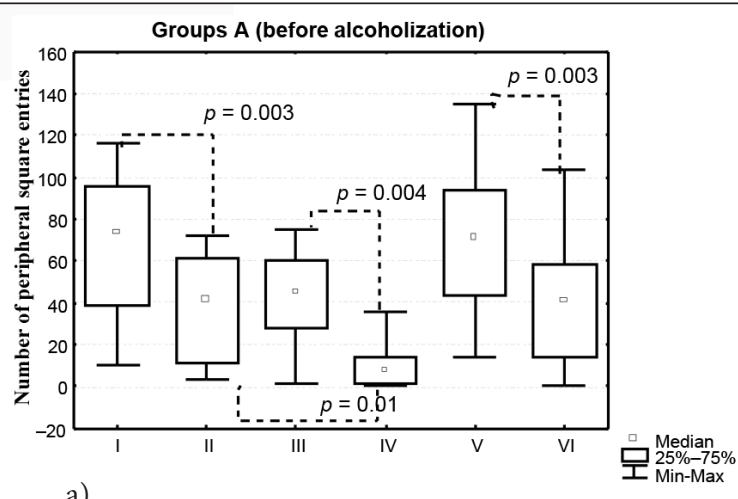

a)

Subgroup

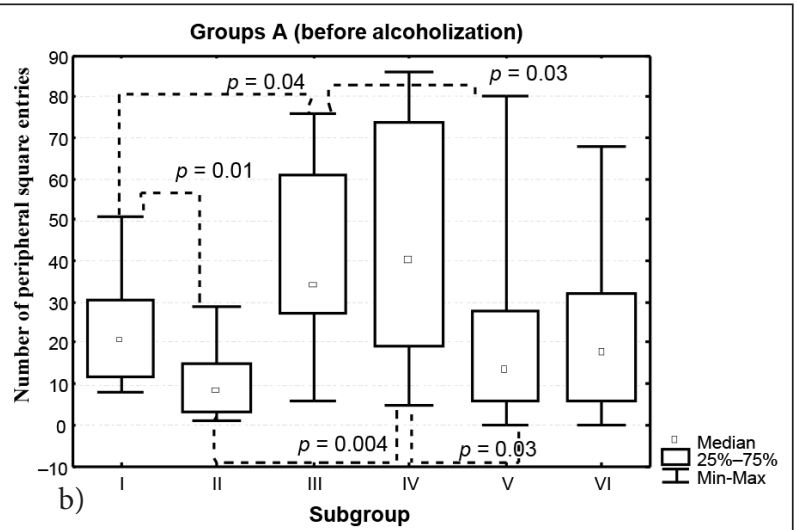

Fig. 5. Number of peripheral square entries, in the open field test, before (a) and after (b) alcoholization in the rats from group A, subgroups I-VI
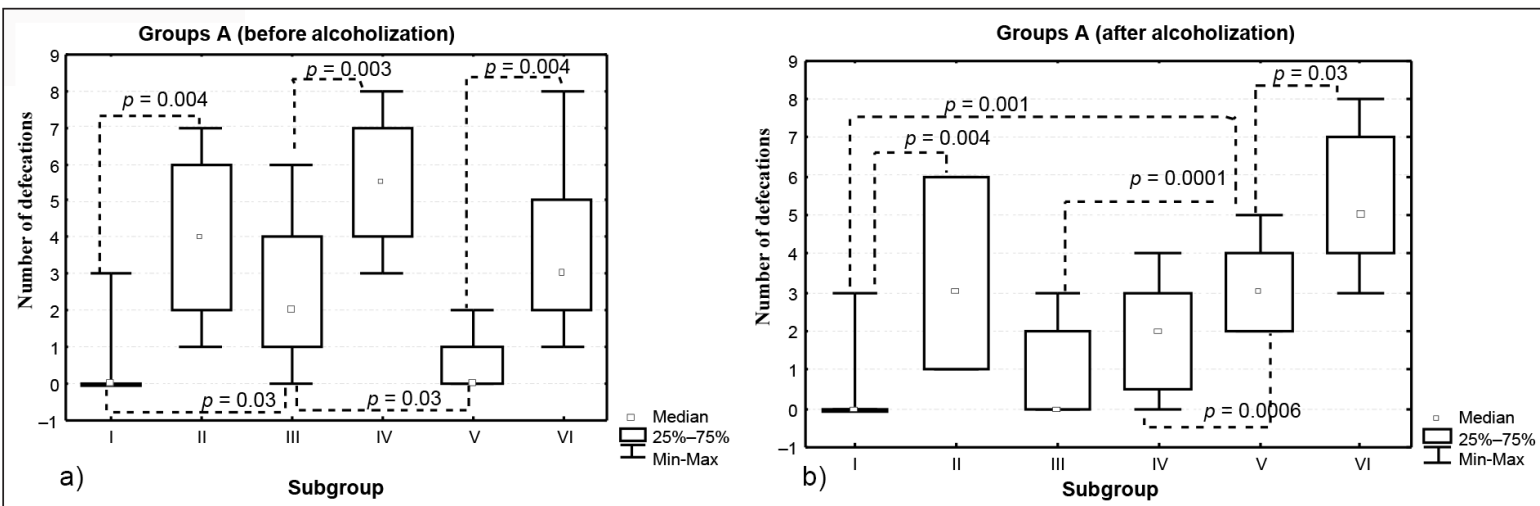

Fig. 6. Number of defecations in open field test, before (a) and after (b) alcoholization, in the rats from group A, subgroups I-VI
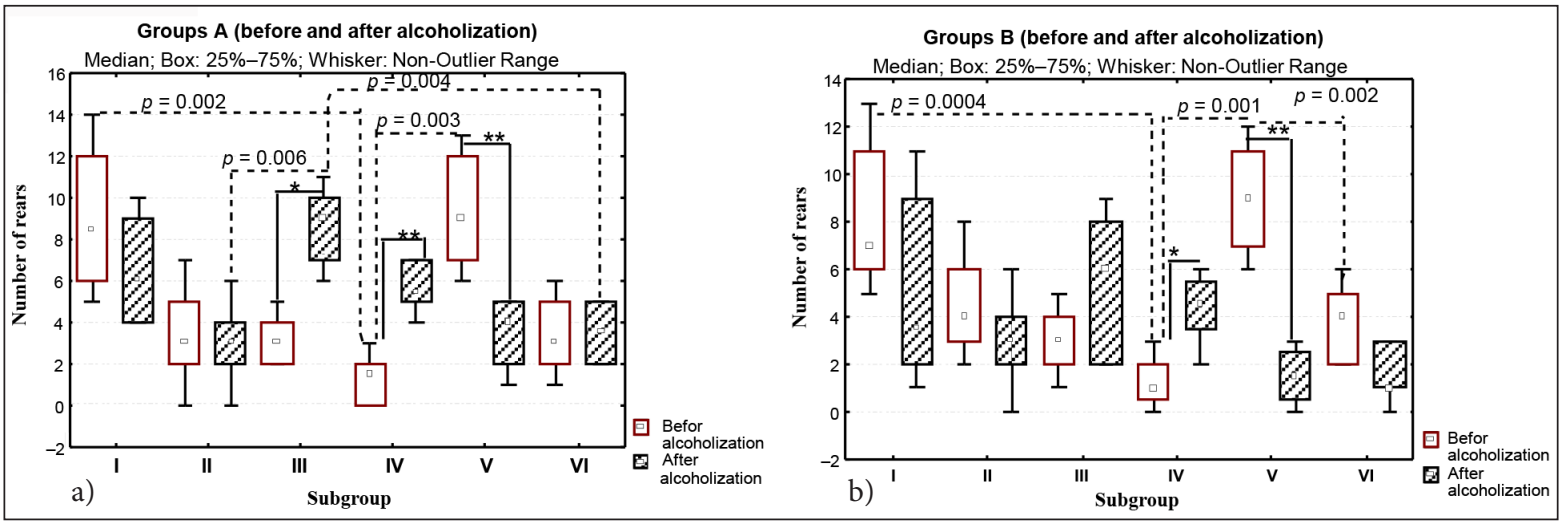

Fig. 7. Number of rears in the open field test, before and after alcoholization in the rats from group A (a) and B (b), subgroups I-VI. ${ }^{\star} p \leq 0.05 ;{ }^{* *} p \leq 0.01$ 
a higher number of peripheral square entries $(p \leq 0.003)$ and the number of center square entries $(p \leq 0.02)$ compared with the rats from VI (A) (Fig. 5a). The number of acts of defecation in the rats from subgroups III (A) and V (A) was significantly lower than in the rats from subgroups IV (A) and VI (A): $(p \leq 0.003)$ and $(p \leq 0.004)$, respectively (Fig. 6a). In addition, alcohol-preferring rats (subgroups $\operatorname{III}(\mathrm{A})$ and $\mathrm{V}(\mathrm{A})$ ) had a lower initial level of locomotor activity, and a higher level of emotional activity compared with animals of other subgroups (number of peripheral square entries $(p \leq 0.01)$ and number of defecations ( $p \leq 0.03$ ) with control) (Fig. 5a). The differences in individual reactivity in the $\mathrm{OF}$ among the subgroups of groups A and B had the same tendency.

The level of individual reactivity of alcoholprefering rats and alcohol-non-preferring rats after alcoholization and training was significantly lower in the animals from group B compared with group A: in subgroup III (B), the number of peripheral square entries $(p \leq 0.01)$ and the number of rears $(p \leq 0.03)$ were lower, and the number of acts of defecation $(p \leq 0.03)$ was higher; in subgroup IV (B) the number of peripheral square entries $(p \leq 0.004)$ and the number of rears $(p \leq 0.03)$ were lower; in subgroup $\mathrm{V}(\mathrm{B})$, the number of peripheral square entries $(p \leq 0.01)$ was lower; in subgroup VI (B), the number of peripheral square entries ( $\mathrm{p} \leq 0.01$ ) was lower and the number of acts of defecation ( $p \leq 0.009)$ was higher (Fig. 8).

\section{DISCUSSION}

It has been shown that behavioural activity can be a prognostic criterion for determining the susceptibility to alcohol and that rats predisposed to alcoholism have high levels of emotional and anxiety and low locomotor and exploratory activity.

Ethanol in alcohol-dependent rats had a pronounced anxiolytic effect and improved the rates of speed and efficiency of assimilation of information in the radial maze. Chronic use of ethanol in rats non-susceptible to alcohol reduced the rate of success of training and increased their level of anxiety, especially when ethanol was used before the beginning of training. In addition, to some extent learning in a maze before the beginning of alcoholization leveled off the negative influence of alcohol in the animals with low alcohol motivation.

Thus, it has been shown that the level of anxiety-neurotic reactions decreased in alcohol-dependent animals, and their level of exploratory activity was higher than in control animals. Moreover, in the rats that were well trained, the level of anxiety declined more than in poorly trained rats. In alcohol-nondependent animals, taking ethanol increased manifestations of anxiety and neurotic reactions, especially in poorly trained animals. These results show that the speed of learning correlates with the level of fear, anxiety, and the level of motor activity. The rats with a low level of fear and

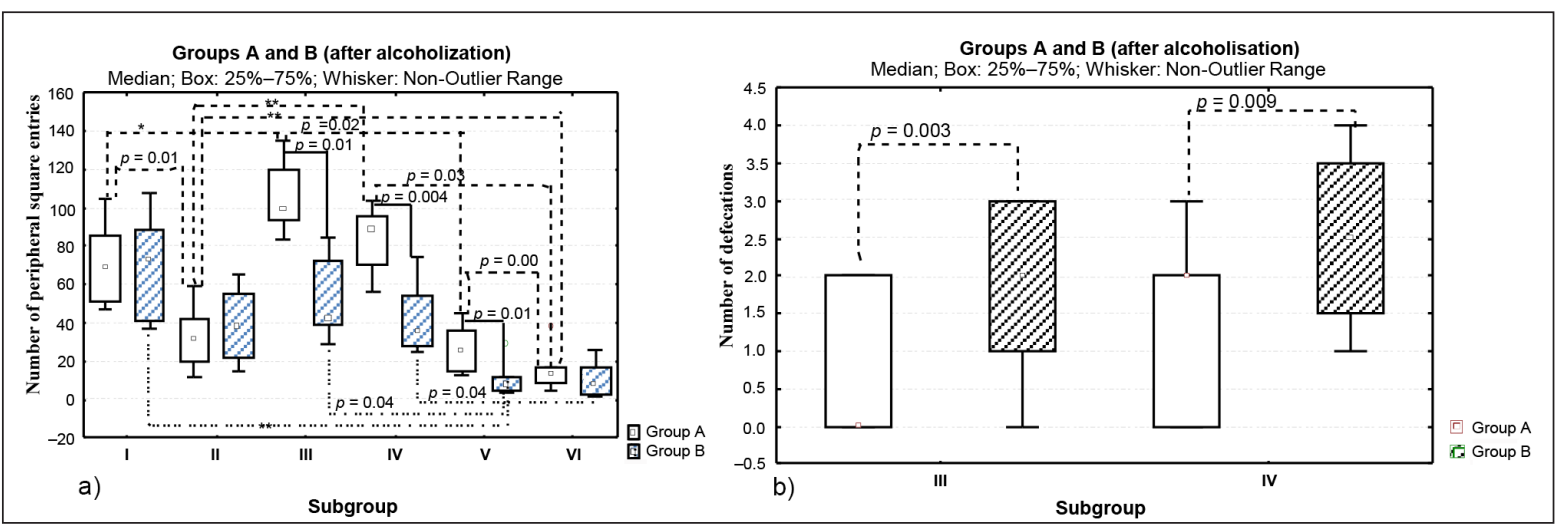

Fig. 8. Number of peripheral square entries (a) and the number of defecations (b), in the open field test after alcoholization in the rats from groups $\mathrm{A}$ and $\mathrm{B}{ }^{\star} p \leq 0.05 ;{ }^{* *} p \leq 0.01$ 
anxiety had a high level of training in the RM. This confirms the hypothesis that a high level of anxiety contributes to the development of a predisposition to alcohol due to its anxiolytic effects (Becker et al., 2011; Lopez et al., 2016; Richard et al., 2006; Shabanov et al., 1999; Spanagel et al., 2014). Alcoholization disrupts higher brain functions and short-term memory and promotes stereotyped behaviour, reducing the number of animals that coped with the task of finding food in the labyrinth. At the same time, learning of animals before the start of alcohol abuse reduced the negative influence of alcohol on behavioural characteristics. There exists experimental data on improving the execution of the some behavioural tasks after drinking ethanol (Richard et al., 2006). In addition, the difference in the level of learning between animals with different alcoholic motivation indirectly demonstrates increased sensitivity of systems of positive reinforcement of the brain in animals predisposed to alcohol, because ethanol, as a tranquilizer, has a stimulating effect on these systems (David et al., 1999; Parkhomenko et al., 2007; Spanagel et al., 2014; Shabanov et al., 2002; Vengeliene et al., 2008). This effect can be associated with the learning process and the formation of a memorable trace in the structures of the nervous system. At the cellular level, this means that processes that increase the resistance of tissues to the action of the pathogenic factor-ethanol are triggered.

\section{CONCLUSIONS}

The study demonstrated that the process of learning before alcohol abuse had a positive effect on behaviour (reduced the amount of alcohol-preferring animals) and reduced the negative influence of alcohol on behavioural characteristics, while alcoholization before learning increased the level of anxiety and neurotic reactions in animals, especially in the rats with an initially low level of learning.

The most negative influence of alcohol on the behaviour was shown in the animals with low innate activity and an initially low level of learning.
The study confirmed the hypothesis that a high level of anxiety contributed to the development of a predisposition to alcohol due to its anxiolytic effects and the learning speed correlated with the level of fear, anxiety, and the level of motor activity.

The data obtained are important for further evaluation influence of learning and of the emotional component on predisposition to alcohol.

Received 12 June 2018

Accepted 14 May 2019

\section{References}

1. Alexandrov YuI, Grechenko TN, Gavrilov VV, Gorkin AG, Shevchenko DG, Grinchenko YuV, Aleksandrov IO, Maksimova NE, Bezdenezhnych BN, Bodunov MV. Formation and realization of individual experience. Neurosci Behav Physiol. 1997: 27(4): 441-54.

2. Alexandrov YuI, Grinchenko YuV, Mats VN, Laukka S, Korpusova AV. Involvement of rabbit motor cortex neurons in the instrumental behaviour before and after chronic ethanol treatment consumption: a comparison with the limbic cortex . Zh Vyssh Nerv Deiat Im. 2002; 52(1): 85-6. Russian.

3. Becker HC, Lopez MF, Doremus-Fitzwater TL. Effects of stress on alcohol drinking: a review of animal studies. Psychopharmacology. 2011; 218(1): 131-56.

4. Bell RL, Rodd ZA, Lumeng L, Murphy JM, McBride WJ. The alcohol-preferring P rat and animal models of excessive alcohol drinking. Addict Biol. 2006; 11(3-4): 270-88.

5. Belzung C, Griebel G. Measuring normal and pathological anxiety-like behaviour in mice: a review. Behav Brain Res. 2001; 125(1-2): 141-9.

6. Bondarenko OV, Hula NM, Makarchuk MYu, Horid'ko TM. Effects of N-stearoylethanolamine on anxiety-like behavioural reactions of rats after chronic alcoholization. Biologija. 2014; 60(1): 23-31. 
7. Bogdanov VB, Bogdanova OV, Koulchitsky SV, Chauvel V, Multon S, Makarchuk MY, Brennan KC, Renshaw PF, Schoenen J. Behavior in the open field predicts the number of $\mathrm{KCl}$-induced cortical spreading depressions in rats. Behav Brain Res. 2013; 236(1): 90-3.

8. Buresh Ya, Bureshova O, Houston DP. Methods and basic experiments for studies of brain and behaviour. Moscow: Vysshaya Shkola; 1991: 45-68. Russian.

9. Gould TD. Mood and anxiety related phenotypes in mice. Humana Press. 2009.

10. Kovalenko OA, Ovcharyk EM, Bondarenko OV, Makarchuk MYu. Influence of behavioural reactions on ability to training of rats with different degree of alcoholic motivation. Visnyk of Luhansk National Taras Shevchenko University: Medical sciences. 2010; 21(208): 54-9. Russian.

11. Kurzina NP, Batuev AS, Paranina IN. The effect of alcoholization on the behavioural reactions of rats in an 8-ray radial maze. Zh Vyssh Nerv Deiat Im. 1999; 49(6): 1027-38. Russian.

12. Lopez MF, Anderson RI, Becker HC. Effect of different stressors on voluntary ethanol intake in ethanol-dependent and nondependent C57BL/6J mice. Alcohol. 2016; 51: 17-23.

13. Levin ED. Learning about cognition risk with the radial-arm maze in the developmental neurotoxicology battery. Neurotoxicol Teratol. 2015; 52(A): 88-92.

14. Overstreet DH, Rezvani AH, Parsian A. Behavioural features of alcohol-preferring rats: focus on inbred strains. Alcohol and Alcoholism. 1999; 34(3): 378-85.

15. Parkhomenko Yu M, Donchenko GV, Pylypchuk SYu, Stepanenko SP, Chekhovskaia LI, Klimenko EP. Characteristic metabolic distur- bances in the rat tissues caused by long-term use of alcohol. Ukr Biokhim Zh. 2007; 79(3): 61-9. Russian.

16. Pfaff DW, Martin EM, Ribeiro AC. Relations between mechanisms of CNS arousal and mechanisms of stress. Stress. 2007; 10(4): 316-25.

17. Risher ML, Fleming RL, Boutros N, Semenova S, Wilson WA, Levin ED, Markou A, Swartzwelder HS, Acheson SK. Long-term effects of chronic intermittent ethanol exposure in adolescent and adult rats: radial-arm maze performance and operant food reinforced responding. PLoS One. 2013; 8(5): e62940.

18. Romeo RD, Bellani R, Karatsoreos IN, Chhua N, Vernov M, Conrad CD, McEwen BS. Stress history and pubertal development interact to shape hypothalamic-pituitaryadrenal axis plasticity. Endocrinology. 2006; 147(4): 1664-74.

19. Shabanov PD, Kalishevich SY. Biology of alcoholism. 1999; 1: 100-15. Russian.

20. Shabanov PD, Lebedev AA, Meshcherov ShK. Activation of ethanol by the mechanisms of brain reinforcement. Experimental Narcology. 2002; 6: 8-11. Russian.

21. Spanagel R, Noori HR, Heilig M. Stress and alcohol interactions: animal studies and clinical significance. Trends Neurosci. 2014; 37(4): 219-27.

22. Vengeliene V, Bilbao A, Molander A, Spanagel R. Neuropharmacology of alcohol addiction. Br J Pharmacol. 2008; 154(2): 299315.

23. Volchegorskii IA, Dolgushin II, Kolesnikova OL, Tseilikman VE. Experimental modeling and the laboratory evaluation of body's reactions. Chelyabinsk: Chelyabinsk State Pedagogical University Press; 2000. 


\section{Olga Kovalenko, Oleksandr Bondarenko, Irina Tubaltseva, Mukola Makarchuk \\ RYŠYS TARP TRENIRAVIMO IR ALKOHOLI- ZACIJOS: ŽIURKIŲ ATVEJIS}

\section{Santrauka}

Darbo tikslas - nustatyti ryši tarp jaunų žiurkių patinų treniravimo, igimto elgesio ir piktnaudžiavimo alkoholiu. Tyrimo metu buvo taikomi ịvairūs treniruočių deriniai su alkoholizacija, be to, žiurkès pasižymèjo skirtinga priklausomybe nuo alkoholio. Nustatyta, kad šią priklausomybę turinčioms nuo alkoholio žiurkėms, palyginti su jos neturinčiomis, būdingas emocionalumas, nerimas, silpnesnis lokomotorinis ir tiriamasis aktyvumas. Stipriausias neigiamas piktnaudžiavimo alkoholiu poveikis elgesiui buvo nustatytas silpną igimtą aktyvumą turintiems gyvūnams ir netreniruotiems labirintuose. Pastebèta, kad žiurkių treniravimas labirintuose, prieš pradedant vartoti alkoholi, turẻjo teigiamą poveikị jų elgesiui - sumažèjo alkoholị vartojančių žiurkių skaičius. Gyvūnų alkoholizacija prieš treniruotę padidino nerimo ir neurotinių reakcijų lygi, ypač tų žiurkių, kurios prieš alkoholizaciją nebuvo treniruojamos labirintuose.

Raktažodžiai: paruošimas, treniravimas, Ł̇gimtas elgesys, alkoholizacija 